\title{
Habitat use of a Critically Endangered elasmobranch, the largetooth sawfish Pristis pristis, in an intermittently flowing riverine nursery
}

\author{
Jeff M. Whitty ${ }^{1,}{ }^{*}, J^{\prime}$ ames Keleher ${ }^{1}$, Brendan C. Ebner ${ }^{2,3}$, Adrian C. Gleiss ${ }^{1}$, \\ Colin A. Simpfendorfer ${ }^{4}$, David L. Morgan ${ }^{1}$ \\ ${ }^{1}$ Freshwater Fish Group \& Fish Health Unit, Centre for Fish \& Fisheries Research, Murdoch University, Murdoch, \\ Western Australia 6150, Australia \\ ${ }^{2}$ TropWATER - Centre for Tropical Water and Aquatic Ecosystem Research, James Cook University, Townsville, \\ Queensland 4811, Australia \\ ${ }^{3}$ CSIRO Land and Water, Atherton, Queensland 4883, Australia \\ ${ }^{4}$ Centre for Sustainable Tropical Fisheries and Aquaculture, and College of Marine and Environmental Sciences, \\ James Cook University, Townsville, Queensland 4811, Australia
}

\begin{abstract}
Knowledge of how an animal uses its habitat is a fundamental component of effective conservation strategies. The Critically Endangered largetooth sawfish Pristis pristis uses rivers and their estuaries as nursery habitats, where it is likely to be exposed to elevated pressures from anthropogenic-induced stresses including fishing (e.g. bycatch or direct harvest) and instream habitat modification and degradation (e.g. barriers, water extraction, and mining). With a paucity of data available on habitat use of $P$. pristis, we monitored the movements of 32 juveniles (952 to $2510 \mathrm{~mm}$ total length; mean $\pm \mathrm{SE}=1919 \pm 64 \mathrm{~mm}$ ) using acoustic telemetry to explore correlations between sawfish movement and abiotic as well as biotic variables over an 8 yr period (2008 to 2015) in the freshwater reaches of the Fitzroy River, Western Australia. Monitored juveniles were least active when they occupied deeper runs and pools in proximity to large woody debris by day and were most active during night-time and twilight hours when inhabiting shallow water such as glides, pool edges, and shallow runs. These shifts in activity and habitat use were primarily mediated by foraging and refuging behaviours, which were coupled to day-night cycling of light availability. Protection of these instream habitats and the understanding of their use by P. pristis are important for aiding in the management of intermittently flowing rivers that are used as nurseries for this species.
\end{abstract}

KEY WORDS: Diel activity $\cdot$ Acoustic telemetry $\cdot$ Large woody debris $\cdot$ Dry season $\cdot$ Pristidae

\section{INTRODUCTION}

Nearshore environments, including marine embayments, estuaries, and even freshwater reaches of rivers, are used by a number of elasmobranch species as nurseries because these environments frequently offer relatively high prey availability and a decreased predation risk (Castro 1993, Beck et al. 2001, Heupel et al. 2007). However, anthropogenic pres-

\footnotetext{
*Corresponding author: jeffmwhitty@hotmail.com
}

sures can negatively affect elasmobranchs in these nursery areas and have resulted in decreased ontogenetic resource partitioning (Carlisle \& Starr 2009), emigration of juveniles into less favourable environments (Simpfendorfer et al. 2005, Carlisle \& Starr 2009), and reductions in rate of survival (Jennings et al. 2008). While it is rare that large rivers are given complete protection from development, it is important to minimise disturbances to resources of a habi-

(C) The authors 2017. Open Access under Creative Commons by Attribution Licence. Use, distribution and reproduction are unrestricted. Authors and original publication must be credited. 
tat that a species of concern is dependent on. This is particularly vital for highly threatened and philopatric elasmobranchs, especially those that depend on nurseries that are sparsely distributed along expansive coastlines, as is the case with large rivers and their estuaries (Phillips et al. 2017).

Resources that are important to a species can be identified through understanding how a species uses its habitat. Habitat use has been defined as 'the way an animal uses (or 'consumes', in a generic sense) a collection of physical and biological components'(Hall et al. 1997). According to the optimisation theory, as used in behavioural ecology, an animal will use the various components of its habitat in a way that it can maximise its potential fitness (MacArthur \& Pianka 1966, Werner et al. 1983, Hugie \& Dill 1994, Krause et al. 1998, Sims 2003). However, the resources required by a species may vary between meso- or microhabitats, forcing an individual to move between these environments in order to acquire vital resources. Shortterm (i.e. diel) vertical and horizontal shifts between environments are a relatively common behaviour observed in elasmobranchs and are often used for thermoregulation (Matern et al. 2000, Sims et al. 2006), to increase prey accessibility (i.e. for foraging purposes) (Ackerman et al. 2000, Cartamil et al. 2003), or to decrease predation risk (Holland et al. 1993). Habitat use can be complex and is often a balance between the rewards and risks associated with multiple abiotic and biotic variables. For example, although a certain habitat type might prove optimal to an animal due to the abundance of prey, if the predation risk is too great, the animal is likely to select an alternative habitat (Heithaus \& Dill 2006). Spatial and temporal changes of the abiotic and biotic factors that shape the manner with which individuals select habitat also add to the complexity of habitat use.

The largetooth sawfish Pristis pristis is a diadromous elasmobranch that is listed as Critically Endangered by the International Union for Conservation of Nature (IUCN) (Kyne et al. 2013). The geographic range and numbers of $P$. pristis have greatly declined because of habitat modifications and fishing (White \& Kyne 2010, Everett et al. 2015, Dulvy et al. 2016). Pristis pristis is the only circumtropical species of sawfish, with the other species limited to the Atlantic or Indo-West Pacific oceans. Despite northern Australia being one of the last strongholds for $P$. pristis (Thorburn et al. 2007, Peverell 2008, Morgan et al. 2011, Phillips et al. 2011), this species remains listed as Vulnerable under the Federal Government's Environment Protection and Biodiversity Conservation Act. Juvenile $P$. pristis are especially vulnerable to anthropogenic pressures in regions like Australia where they are pupped in or near large rivers, which they use as nurseries for 4 to $5 \mathrm{yr}$ (Thorburn et al. 2007, Whitty 2011). Juvenile $P$. pristis may use the entirety of a river if not obstructed by natural or anthropogenic barriers.

Rivers within northern Australia have been targeted for developments that will supply water and energy to the growing human population. However, it is uncertain how and to what degree such disturbances will affect juvenile $P$. pristis due to the limited knowledge of the habitat use of the species. Previous studies have provided valuable information regarding habitat use of age $0+$ and $1+P$. pristis $(<1611 \mathrm{~mm}$ total length [TL]) in estuarine and freshwater habitats (Whitty et al. 2009, Gleiss et al. 2016) but lacked observations of older cohorts within the nursery and were limited to analysis of vertical movements. However, riverine environments display substantial variations in habitat characteristics over the horizontal plane, which may serve important functions in the ecology of the species.

The objective of this study was to provide a detailed understanding of the habitat use of multiple age-classes of juvenile $P$. pristis in an intermittently flowing riverine nursery and to evaluate if the species displayed preference for particular habitats or resources in the area. To do so, we monitored juvenile $P$. pristis vertical and horizontal movements as well as abiotic and biotic variables in the dry season within isolated freshwater reaches of the Fitzroy River, Western Australia.

\section{MATERIALS AND METHODS}

\section{Study site}

This study was conducted in the freshwater reaches of the Fitzroy River, Western Australia (Fig. 1) during the 2008 to 2015 dry seasons (May or June to November). Limiting the study period to the dry season allowed for continuous monitoring of largetooth sawfish Pristis pristis over several months (when they were trapped in isolated reaches as discussed below) and prevented disruption of acoustic tag transmissions by high river flows. This dynamic environment experiences extreme seasonal changes in precipitation, evaporation, and temperature (Whitty 2011), with precipitation restricted to a distinct wet season (December to April). River stage height and discharge decrease progressively during the dry season, and the river is transformed into a series of isolated 


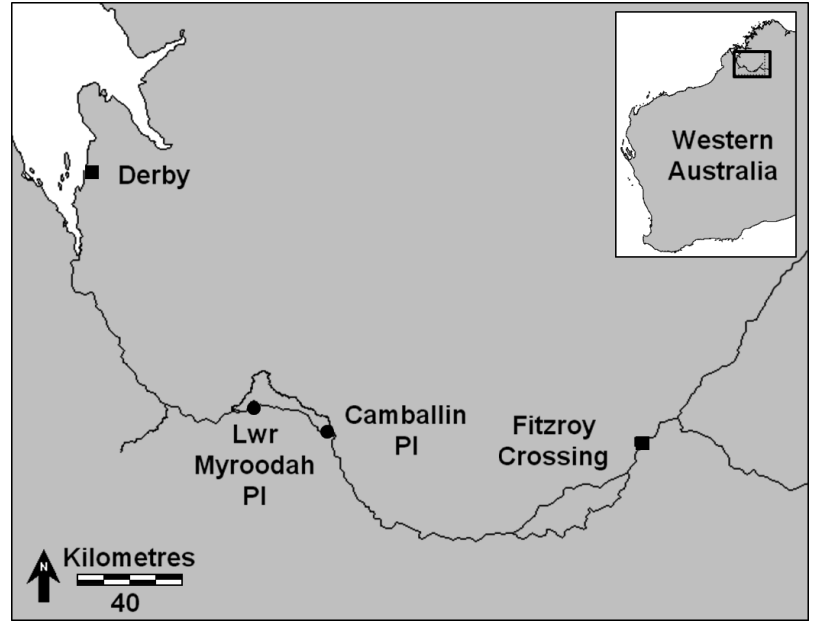

Fig. 1. Locations of the monitored reaches (dots) on the Fitzroy River, Western Australia. Pl: Pool; Lwr: Lower

reaches (defined here as an uninterrupted stretch of river), many of which are sustained by alluvial aquifers. During this time, fish become trapped within these isolated freshwater reaches or in the estuarine region of the river. Reaches become reconnected and movement into and out of the river becomes possible in the wet season when monsoonal rains substantially increase river stage height. However, wet season river discharge and stage height are subject to annual variations in precipitation (Whitty 2011).

Two freshwater reaches of the Fitzroy River were monitored: Lower Myroodah Pool (located 126 km upstream from the river mouth) and Camballin Pool (located $160 \mathrm{~km}$ upstream from the river mouth). Lower Myroodah Pool and Camballin Pool were approximately $0.06 \mathrm{~km}$ in width and 3.0 and $2.5 \mathrm{~km}$, respectively, in length. These reaches were selected for this study because of their accessibility, the presence of sawfish, and their representation of the prevalent habitat-type of the freshwater reaches of the Fitzroy River (i.e. meandering main channel with vegetated cover and substrate composed largely of sand). Freshwater reaches compose the greatest percentage of the $P$. pristis Fitzroy River nursery ( 400 km in length), with large ( 9 to $>11 \mathrm{~m}$ ) tides only affecting the lower $\sim 17 \mathrm{~km}$ of the river.
Reaches were further divided into 3 mesohabitat types: pools, glides, and runs (Figs. 2 \& 3). Pools were characterised by deep, slow-moving water and were located on the outer upstream edge of a meander in the river. Glides consisted of shallow environments located immediately downstream of pools where the channel narrowed and flowed adjacent to a prominent and exposed sandbar. Prominent glides were located near the ends of each monitored reach. Runs consisted of sections of a reach with a smooth surface and with water depths that reflected those of neighbouring mesohabitats (i.e. deep depths near pools and shallow depths near glides). In this study, a run was considered to be the straight section of a reach that was located upstream of a pool and downstream of a glide. Reaches were terminated and separated by riffles, which were $\leq 5 \mathrm{~km}$ in length. Riffles consisted of extreme shallow water that became impassable and exposed during the late dry season when water temperature and rates of evaporation increased (Whitty 2011). Although a reach may contain multiple pools, runs, or glides, when present, riffles were located downstream of a glide and upstream of a pool or run.

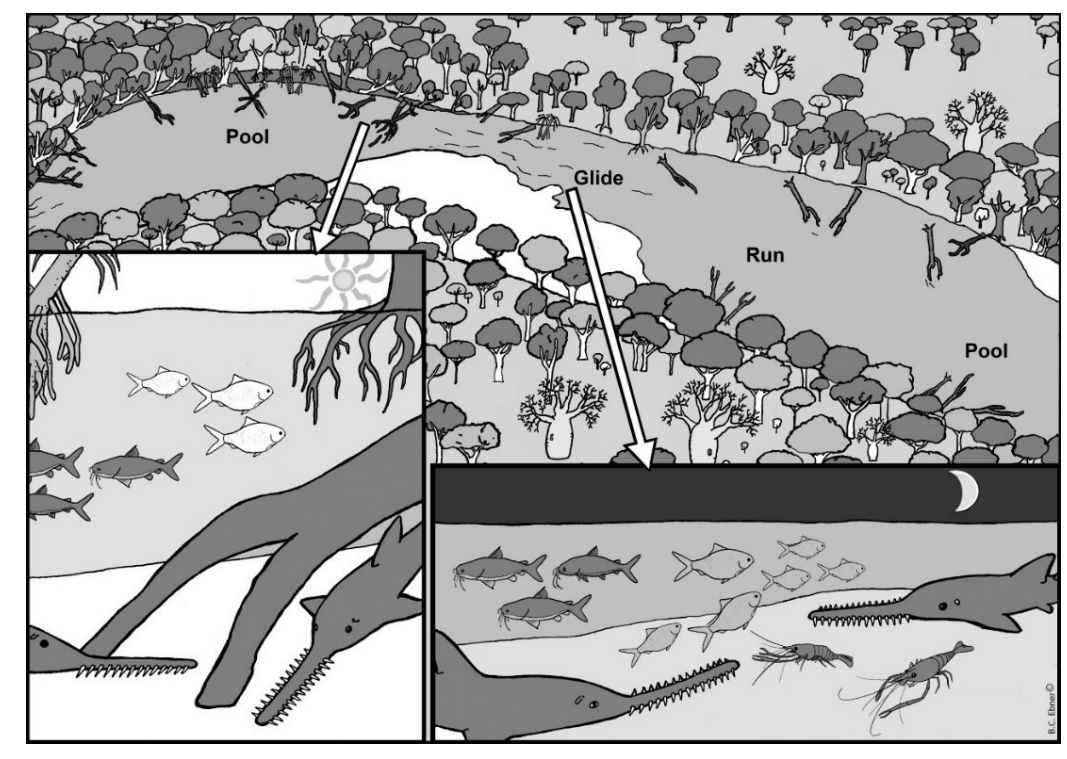

Fig. 2. Schematic of the mesohabitat pattern within the meandering freshwater reaches of the Fitzroy River, Western Australia (flows left to right): a deep pool on the upper and outer portion of a meander, a shallow glide at the downstream portion of a meander (parallel to a large exposed sandbar), and a run in the straightaway. This pattern repeats until termination of the reach. In the dry seasons, reaches are separated by extremely shallow and impassable riffles (not illustrated). Riffles occur downstream of glides and upstream of runs or pools. Depth and large woody debris concentrations are generally greatest in pools and smallest in glides (see Fig. 3). Juvenile $(>0+)$ largetooth sawfish Pristis pristis take refuge in deep runs and pools in day-time hours and forage in shallow runs and glides during night-time and twilight hours, where and when concentrations of prey increase. Illustration by B. C. Ebner 


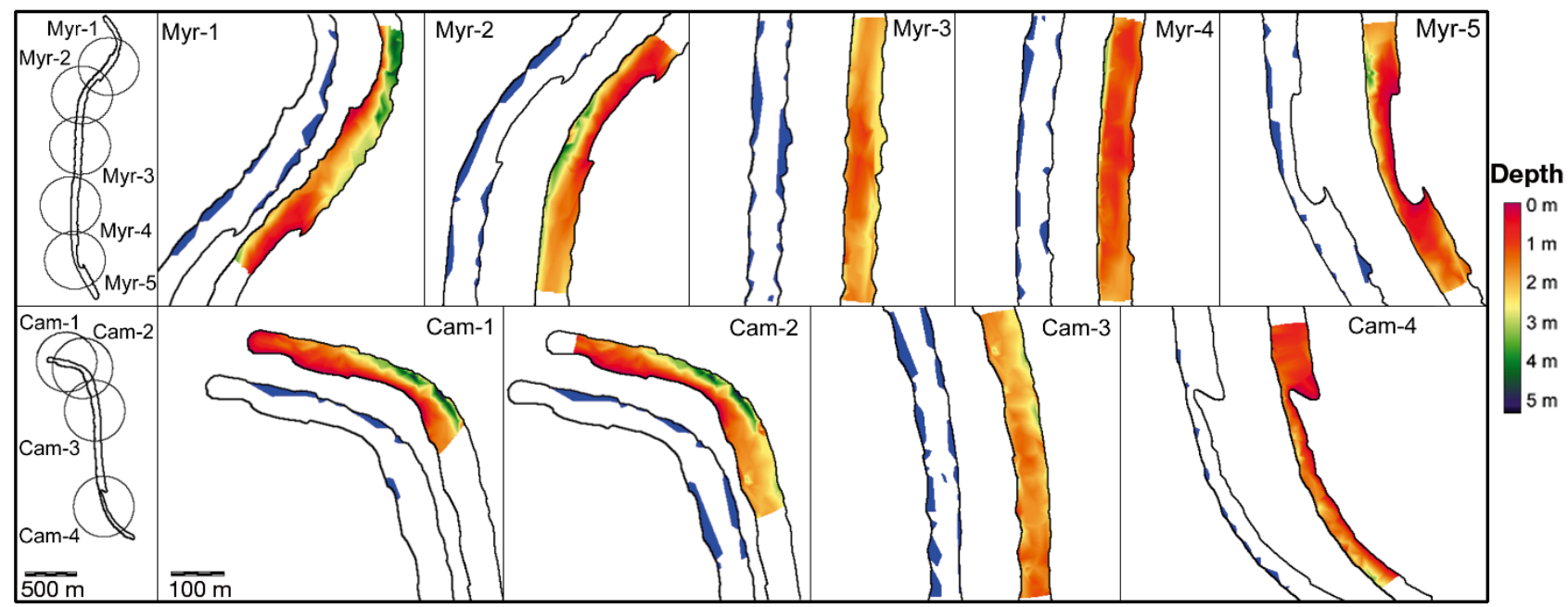

Fig. 3. Depth (coloured gradient) and large woody debris (blue shading) of acoustically monitored regions in lower Myroodah (Myr) Pool and Camballin (Cam) Pool. Diagrams on the left denote detection ranges of acoustic receivers within each pool. Receivers Myr-1, 3, and 4 and Cam-3 were located in runs, Myr-2 and Cam-2 in pools, and Myr-5 and Cam-1 and 4 in glides, although some receivers may have detected tags in portions of neighbouring mesohabitats on occasion

\section{Acoustic array and range tests}

One to 5 Vemco VR2W acoustic receivers (Vemco Divison, Amirix Systems) were installed in each reach. The array was not static and changed in number and coverage due to the additional deployment of, or inability to download, receivers. Not being able to download data from a receiver was equivalent to having no receiver at the location and caused coverage of a reach to be temporarily incomplete. Statistical analyses were chosen and adjusted to accommodate for the varying receiver coverage. For example, comparisons were drawn between hours or periods of the day at a receiver, rather than between receivers. Receivers were affixed to moorings, which were installed at sites chosen according to depth, available anchoring points, lack of obstructions to acoustic signals (e.g. trees or river meanders), distance to neighbouring receivers, and mesohabitat unit type (i.e. pool, run, or glide). Each acoustic receiver was assigned to the mesohabitat type that dominated the detection area of the respective receiver: 4 receivers were placed in runs, 2 in pools and 3 in glides (Tables $1 \& 2$, Fig. 3). Receivers were downloaded and serviced semiannually.

Distances at which receivers could detect acoustic transmitters were tested using methods described by Whitty et al. (2009). Specifically, range tests were undertaken by mooring Vemco V13-1L continuous 'test-tags' $1 \mathrm{~m}$ above the river floor (to replicate the benthic behaviour of sawfish and to prevent burial of the tag) at $50 \mathrm{~m}$ intervals up and downstream of re- ceivers for periods of 5 min. Receivers were determined to be sufficient in detecting transmissions at a given distance if $95 \%$ of expected transmissions (test duration $\times$ tag transmission rate) were observed for that interval. Detection range of receivers was up to $400 \mathrm{~m}$, with $95 \%$ of expected transmissions occurring at $300 \mathrm{~m}$.

\section{Sampling and tagging}

Juvenile $P$. pristis were captured using gill nets or hook and line (see Whitty et al. 2009 for a detailed description). Upon capture, sawfish were transported to the shoreline to be measured, sexed, and tagged. Sawfish were tagged with individually numbered Rototags (Dalton Supplies) and with Vemco acoustic V13-1L tags. Acoustic tags transmitted at a frequency of $69 \mathrm{kHz}$ and at a random interval. Transmission intervals varied in some years and ranged between 45 and $180 \mathrm{~s}$. Transmission intervals were randomised to reduce overlap of acoustic transmissions from multiple tags. All but 2 tags (1068356 and 1068358) were equipped with pressure sensors.

Tags were attached externally to $P$. pristis between 2008 and 2013. Following Whitty et al. (2009), externally attached acoustic tags were secured to Rototags with multiple cable ties coated in marine-grade silicone and fitted to the first dorsal fin. In 2014 and 2015, a portion of the deployed acoustic tags were placed internally to determine if this method would increase duration of tag retention for a simultane- 
Table 1. Summary of largetooth sawfish Pristis pristis tagged and detected during the dry season (May to November) 2008 to 2015 in Camballin Pool and lower (Lwr) Myroodah Pool, Fitzroy River, Western Australia. TL: total length; \# days monitored: number of days (in the dry season) between when the fish was tagged and when it was last detected; \# days detected: number of days (in the dry season) a sawfish was detected by at least 1 receiver

\begin{tabular}{|c|c|c|c|c|c|c|c|}
\hline Tag & Sex & $\mathrm{TL}(\mathrm{mm})$ & Site of release & Date of capture & $\begin{array}{c}\text { Date of last } \\
\text { detection }\end{array}$ & $\begin{array}{c}\text { \# days } \\
\text { monitored }\end{array}$ & $\begin{array}{c}\text { \# days } \\
\text { detected }\end{array}$ \\
\hline 1061752 & $\mathrm{~F}$ & 2142 & Lwr Myroodah Pool & 27-Oct-08 & 24-Nov-08 & 29 & 25 \\
\hline 1061751 & M & 2210 & Camballin Pool & 28-Oct-08 & 30-Nov-08 & 34 & 32 \\
\hline 1068356 & $\mathrm{~F}$ & 952 & Camballin Pool & 13-May-09 & 02-Jul-09 & 51 & 20 \\
\hline 1068358 & $\mathrm{~F}$ & 1027 & Camballin Pool & 13-May-09 & 30-Jun-09 & 49 & 35 \\
\hline 1096394 & M & 2070 & Lwr Myroodah Pool & 31-Jul-10 & 30-Nov-10 & 123 & 122 \\
\hline 1096389 & $\mathrm{~F}$ & 2144 & Lwr Myroodah Pool & 1-Aug-10 & 30-Nov-10 & 122 & 122 \\
\hline 1143403 & $\mathrm{~F}$ & 2300 & Camballin Pool & 10-Aug-12 & $30-N o v-12$ & 113 & 112 \\
\hline 1143404 & M & 1700 & Camballin Pool & 10-Aug-12 & 30-Nov-12 & 113 & $18^{\mathrm{a}}$ \\
\hline 1143399 & $\mathrm{~F}$ & 1690 & Camballin Pool & 11-Aug-12 & 30-Nov-12 & 112 & 108 \\
\hline 1143400 & M & 1698 & Camballin Pool & 11-Aug-12 & 30-Nov-12 & 112 & 105 \\
\hline 1143406 & $\mathrm{~F}$ & 1675 & Camballin Pool & 11-Aug-12 & 30-Nov-12 & 112 & 112 \\
\hline 1143410 & $\mathrm{~F}$ & 1870 & Camballin Pool & 11-Aug-12 & 30-Nov-12 & 112 & 107 \\
\hline 1143411 & M & 1705 & Camballin Pool & 11-Aug-12 & 30-Nov-12 & 112 & 112 \\
\hline 1143412 & M & 1776 & Camballin Pool & 11-Aug-12 & 26-Aug-12 & 16 & 15 \\
\hline 1143407 & M & 1740 & Lwr Myroodah Pool & 12-Aug-12 & 13-Sep-12 & 33 & 31 \\
\hline 1143398 & $\mathrm{~F}$ & 1805 & Camballin Pool & 14-Aug-12 & 30-Nov-12 & 109 & 105 \\
\hline 1143409 & $\mathrm{~F}$ & 1320 & Camballin Pool & 14-Aug-12 & 25-Aug-12 & 12 & 12 \\
\hline 1108784 & M & 1690 & Lwr Myroodah Pool & 23-Oct-12 & 30-Nov-12 & 39 & 33 \\
\hline 1167477 & $\mathrm{~F}$ & 2280 & Camballin Pool & 18-Aug-13 & 29-Aug-13 & 12 & 12 \\
\hline 1167478 & M & 1885 & Camballin Pool & 18-Aug-13 & 30-Nov-13 & 105 & 102 \\
\hline 1167484 & $\mathrm{~F}$ & 2063 & Camballin Pool & 20-Aug-13 & 29-Oct-13 & 71 & 70 \\
\hline 1167487 & $\mathrm{~F}$ & 2310 & Lwr Myroodah Pool & 20-Aug-13 & 29-Nov-13 & 102 & 102 \\
\hline 1167481 & M & 2510 & Camballin Pool & $30-$ Oct-13 & 30-Nov-13 & 32 & 32 \\
\hline 1167482 & M & 1780 & Camballin Pool & 30-Oct-13 & 26-May-14 & 58 & 56 \\
\hline 1183003 & $\mathrm{~F}$ & 2093 & Camballin Pool & 25-Jul-14 & 07-Oct-14 & 75 & 74 \\
\hline 1183004 & M & 1835 & Camballin Pool & 25-Jul-14 & 30-Nov-14 & 129 & 120 \\
\hline 1183005 & $\mathrm{~F}$ & 2145 & Camballin Pool & 26-Jul-14 & 30-Nov-14 & 128 & 125 \\
\hline 1183008 & M & 2062 & Lwr Myroodah Pool & 2-Aug-14 & 25-Oct-15 & 299 & 296 \\
\hline 1167483 & M & 2450 & Lwr Myroodah Pool & 3-Aug-14 & 30-Nov-14 & 120 & 112 \\
\hline 1200100 & M & 2105 & Lwr Myroodah Pool & 12-Oct-14 & 30-Nov-14 & 50 & 50 \\
\hline 1215283 & $\mathrm{~F}$ & 2190 & Lwr Myroodah Pool & 6-Aug-15 & 27-Aug-15 & 22 & $22^{\mathrm{a}}$ \\
\hline 1215284 & M & 2191 & Lwr Myroodah Pool & 6-Aug-15 & $25-$ Oct-15 & 81 & 80 \\
\hline
\end{tabular}

ously run study. Internal tags were disinfected and coated in a paraffin and beeswax mixture. Coated tags were disinfected a second time immediately prior to implantation. Implanted tags were inserted into the peritoneal cavity through a small incision located anterior to the pelvic fins. Incisions were closed with 2 or 3 interrupted sutures of Monosyn absorbable monofilament (B. Braun).

\section{Abiotic and biotic variables}

Water temperature and light intensity were logged by HOBO Pendant Loggers (Onset Computer Corporation), which were installed on acoustic receiver moorings in 2014 and downloaded semiannually in 2014 and 2015. Pendant loggers were deployed on moorings at a depth of $1 \mathrm{~m}$. River stage height data as well as solar and lunar data for the study area were obtained from the Department of Water, Government of Western Australia, and the United States Naval Observatory Astronomical Application Department (http://aa.usno.navy.mil/data), respectively.

Pool depth and occurrence of submerged large woody debris were mapped in both monitored reaches in 2014 and 2015, using a Humminbird Side Imaging sonar unit (Humminbird) in association with a global positioning system (GPS) unit. Pool depths were measured at $10 \mathrm{~s}$ intervals during 2 obliquepatterned transects and a single mid-stream transect. 
Table 2. Lower (Lwr) Myroodah Pool (Pl) and Camballin Pool late dry season mesohabitat composition. Reported mesohabitats are for a $300 \mathrm{~m}$ radius surrounding individual receivers. Depth values and coverage of large woody debris were measured once and are provided to demonstrate the relative scale of each reach. Values of depths vary between months. No major changes in large woody debris were observed during the study period. Mesohabitat: dominant environment within detection range of a receiver; \% debris: percentage of large woody debris (debris in detection range of a receiver/debris in reach)

\begin{tabular}{|lccccc|}
\hline Reach & Receiver & $\begin{array}{c}\text { Meso- } \\
\text { habitat }\end{array}$ & $\begin{array}{c}\text { Mean }( \pm \mathrm{SE}) \\
\text { depth }(\mathrm{m})\end{array}$ & $\begin{array}{c}\text { Max } \\
\text { depth (m) }\end{array}$ & $\begin{array}{c}\% \\
\text { debris }\end{array}$ \\
\hline Lwr Myroodah Pl & Myr-1 & Run & $1.9 \pm 0.001$ & 4.7 & 22.6 \\
Lwr Myroodah Pl & Myr-2 & Pool & $1.7 \pm 0.0009$ & 4.4 & 23.4 \\
Lwr Myroodah Pl & Myr-3 & Run & $1.9 \pm 0.0004$ & 3.1 & 24.9 \\
Lwr Myroodah Pl & Myr-4 & Run & $1.4 \pm 0.0005$ & 3.5 & 18.6 \\
Lwr Myroodah Pl & Myr-5 & Glide & $1.3 \pm 0.0008$ & 4.0 & 13.8 \\
Camballin Pl & Cam-1 & Glide & $1.6 \pm 0.001$ & 5.3 & 16.4 \\
Camballin Pl & Cam-2 & Pool & $1.8 \pm 0.001$ & 5.3 & 37.6 \\
Camballin Pl & Cam-3 & Run & $1.9 \pm 0.0004$ & 3.7 & 52.5 \\
Camballin Pl & Cam-4 & Glide & $1.2 \pm 0.0008$ & 3.4 & 5.8 \\
\hline
\end{tabular}

Water depth did fluctuate through the year, and presented depths should be used as relative measurements. Large woody debris was characterised by objects $\geq 10 \mathrm{~cm}$ in diameter (e.g. snags, large branches, and stumps). This debris was mapped by recording GPS points surrounding the perimeter of each cluster, rather than individual pieces, in essence creating minimum convex polygons for each grouping. Large woody debris structures were generally permanent, and no major changes were observed to occur in the location or abundance of this debris during the study period. The greatest change in debris occurred in early 2008 (prior to the study), when a river bank failure introduced a number of trees into Camballin Pool. The relative coverage of large woody debris as well as mean and maximum depths within a $300 \mathrm{~m}$ radius of each receiver were calculated to determine the available habitat within acoustic range of each receiver. In general, mean depths of monitored areas were greatest in pools and runs and shallowest in glides (Table 2, Fig. 3). Maximum depths were greatest in pools, but because receivers in glides occasionally also covered a portion of a pool, the maximum depths of areas monitored by glide-associated receivers were occasionally just as deep (Fig. 3). Relative coverage of large woody debris in each acoustically monitored area was presented as a percentage of the total coverage of large woody debris within the respective reach and was relatively high in pools and runs, and low in glides (Table 2, Fig. 3).
We also measured the relative abundance of potential sawfish prey and predators in the various hours or mesohabitats to determine what benefits $P$. pristis may gain from moving to shallow habitats at night, as observed in preliminary analyses. Teleosts and crustaceans (i.e. potential sawfish prey species) were sampled throughout the day and night in the shallow waters of glides in the monitored reaches to investigate temporal changes (day vs. night) in relative abundance of these species. Sampling was conducted using a $26 \mathrm{~m}$ beach seine net consisting of two $8 \mathrm{~m}$ wings ( $6 \mathrm{~mm}$ mesh) and a $10 \mathrm{~m}$ pocket ( $3 \mathrm{~mm}$ mesh), which was capable of fishing depths up to $1.5 \mathrm{~m}$. Three samples were taken at each pool at 10:00 h and again at 20:00 h (i.e. 6 samples per day) in the early dry season (June to July) and late dry season (October) of 2007 and 2008. Vessel-based visual assessments of the relatively clear shallow water environments were conducted opportunistically to further investigate differences in abundance and diversity of fishes between day-time and night-time hours. A high-output spotlight was used during night surveys.

Relative abundance of a potential sawfish predator, the freshwater crocodile Crocodylus johnstoni (Morgan et al. 2017), was calculated at night for each mesohabitat in monitored reaches to determine if predation risk varied with habitat type. Counts in the day were not possible as $C$. johnstoni were less active and more difficult to locate or capture at this time. Relative abundance of $C$. johnstoni was estimated following methods similar to Messel (1981). Each reach was divided into multiple $500 \mathrm{~m}$ subsections, which encompassed either shallow glides, pools, or runs. A data recorder, 2 counters, and a boat operator were involved in each survey. Counters were responsible for counting the number of crocodiles on their respective sides of the vessel. Vessel speed was constant throughout each survey. Counters employed high-output spotlights to observe the reflective eyes ('eye-shines') of crocodiles. Eye-shine counts only included those crocodiles on the surface of the water and on land at the time of the count and should be considered a conservative abundance estimate. Counts did not discern size or species, but the number of estuarine crocodiles Crocodylus porosus in the sampled reaches was known to be negligible ( $\mathrm{n}=0$ or 1). Counts were conducted in the early and late dry seasons in 2014 and 2015. 


\section{Data analyses}

We conducted analyses in SigmaPlot 13 (Systat Software) and R 3.2.4 (R Development Core Team 2013). Maps were constructed within IDRISIS Selva 17.0 (Clark Labs). Detections from 2008 to 2015 were included in all analyses unless otherwise stated. All $P$. pristis depth data were acquired from pressure sensors in deployed acoustic tags.

\section{Vertical movements}

A Pearson product-moment correlation was used to test if there was a relationship between TL (1320 to $2510 \mathrm{~mm}$ TL) and mean P. pristis depth. Smaller individuals were not included due to the absence of pressure sensors within their tags. This test was repeated for each monitored week, month, and year. A 2-way repeated-measures analysis of variance (ANOVA) was also run to test if mean $P$. pristis depth varied between hours and months. Data were filtered to only include individuals continuously detected between August and October (see Table 1), to avoid missing values and increase the sample size and thus the power of the test.

The effects of environmental factors on $P$. pristis depth were tested using a generalised additive mixed model (GAMM) performed in R package mgcv (Wood 2006). Depth data were restricted to 2014 and 2015, when continuous monitoring of light intensity and temperature were available and environmental conditions were similar. This analysis was conducted on mean hourly depths for both diel and seasonal patterns to investigate the observed differences in the depths sawfish occupied between hours of the day as well as months. For seasonal (i.e. monthly) analyses, diel patterns were extracted from the data using a moving average of each $24 \mathrm{~h}$ period to reveal the underlying seasonal trend. For diel analyses, no transformation was used; rather, data were truncated to specific weeks of the year, namely Weeks 34 (midAugust) and 43 (mid-October), which negated seasonal effects. These weeks represented the earliest and latest weeks when the majority (>50\%) of the tagged sawfish were monitored (within each week) and when temperature and light data were available. Fixed effects included in the seasonal model were water temperature, light intensity, lunar illumination, and reach (i.e. sawfish location). Individual fish were included as a random factor in each model. Availability of river depth was presumed to influence the depths $P$. pristis inhabited and was taken into ac- count, but was not included in the models because it was strongly correlated with water temperature. The seasonal model was repeated for the diel analyses but excluded lunar illumination because of the shortened time period. The most parsimonious and best fit (lowest Aikaike information criterion [AIC] value/ highest AIC weight; see Burnham \& Anderson 2002) models were selected as those that best explained $P$. pristis depth selection for the 2 temporal scales. Visual inspections of residuals and quantile-quantile plots were used to assess normality. Additionally, Pearson product-moment or Spearman rank-order correlations were run to investigate the relationships between $P$. pristis depth and the fixed effects incorporated in the best fit models.

\section{Horizontal movements}

Time spent at each receiver was estimated by using the number of visits (i.e. 10 min periods within each hour when sawfish were detected) from each animal as a proxy. Visits were used in place of single detections in this analysis to account for varying rates of tag transmissions. A 10 min period was selected as each period allowed for at least 3 transmissions to occur and limited the time-frame to allow for the detection of fine-scale movements. A chi-squared goodness of fit test was used to determine if the number of visits significantly varied by hour. A relative occurrence index was also calculated for each individual at each receiver to allow for visual interpretation of potential differences in sawfish presence between hours of the day. Indices were calculated by dividing the observed number of detections within an hour by an expected number of detections for that hour. The expected number was calculated by dividing the total number of detections for all hours by the number of hours involved (i.e. 24). This established a scale for the index where values of $>1$ indicated a relative preference for a receiver and those $<1$ indicated relative avoidance of a receiver for a given hour. Confidence bands (95\%) for the indices were calculated from standard errors of individual values.

The distance travelled and the number of receivers visited by individual $P$. pristis in each hour of the day were also assessed for $P$. pristis that were continuously detected between August and November in lower Myroodah Pool (see Table 1), where receiver coverage was greatest. The number of receivers visited in each hour were compared using a chi-squared goodness of fit test for individual $P$. pristis to determine if the area of activity decreased 
or increased during the various periods of the day. The distance $P$. pristis travelled was also calculated by summing the distance that an individual moved between receivers for each consecutive pair of detections. Calculated distance should be considered a minimum estimate of total distance travelled because it did not incorporate latitudinal movement or movement that occurred only within the detection range of a single receiver (i.e. movement that did not result in the subsequent detection of an individual at a neighbouring receiver). However, to increase the accuracy of results, transmissions simultaneously detected by 2 receivers, a product of overlapping detection radii of neighbouring receivers, were removed because these represented an individual between 2 receivers rather than in close proximity to a particular receiver. The percentage of the total distance (summing the distance travelled in all periods of the day) a sawfish travelled during day-time (08:00 to 15:59 h), night-time (00:00 to 03:59 $\mathrm{h}$ and 20:00 to 23:59 h) and twilight hours (04:00 to $07: 59 \mathrm{~h}$ and $16: 00$ to $19: 59 \mathrm{~h})$ was calculated to determine if the degree of movement varied between these periods. Twilight hours were expanded from actual times of civil twilight to incorporate seasonal changes in sunrise and sunset and to create a distinct separation between day and night-time hours.

\section{Abiotic and biotic variables}

A Student's $t$-test was used to determine if the difference in relative abundance of $C$. johnstoni (number of $C$. johnstoni $\mathrm{km}^{-1}$ ) significantly differed between glide and non-glide (pools and runs were grouped for this analysis) mesohabitats. Respective mesohabitats in both reaches were pooled to increase sample sizes ( $\mathrm{n}=1$ to 3 within each reach). Student's $t$-tests were also used to test if the relative abundance of known sawfish prey species significantly varied between day-time and night-time periods in shallow water environments.

\section{RESULTS}

Between 2008 and 2015, 32 largetooth sawfish Pristis pristis were tagged and monitored in lower Myroodah Pool and Camballin Pool (Table 1). Tagged $P$. pristis ranged in size between 952 and $2510 \mathrm{~mm}$ TL, with a mean $\pm \mathrm{SE}$ of $1919 \pm 64 \mathrm{~mm}$, representing age 0+ to approximately 5+ (Thorburn et al. 2007,
Peverell 2008). Those with pressure sensors ranged in size between 1675 and 2510 mm TL (i.e. >0+), with an additional individual measuring $1320 \mathrm{~mm}$ TL (1+). The period that $P$. pristis were monitored within the dry season (i.e. the period between when an individual was released and the final day it was detected, excluding days outside of the dry season) ranged between 12 and $299 \mathrm{~d}$ (Table 1). P. pristis were detected on a mean of $91.6 \pm 0.03 \%$ of the number of days that they were monitored (Table 1).

\section{Vertical movements}

A general positive trend was observed between TL and the depth occupied by $P$. pristis when all data were pooled. However, this relationship was not consistent when analysed by week, month, or year. Because of this inconsistency and to increase power of statistical tests, size classes were pooled in analyses. $P$. pristis ( $>0+$ of age) generally occupied deeper water during day-time hours and shallower water during night-time hours (2-way repeated-measures ANOVA, $d f=1, p<0.007$ ) and moved between these depths at sunrise and sunset (Figs. $2 \& 4$ ). Depth data were not available for $0+$ individuals. Mean depths of $>0+$ individuals also significantly decreased between tested months, i.e. August through October (2-way repeated-measures ANOVA, df $=1, \mathrm{p}<0.002$ ), with the greatest changes occurring during day-time hours $($ mean $=1.1 \pm 0.32 \mathrm{~m}$ ) (Fig. 5). River stage height also decreased between these periods. Between August and October 2009 to 2015, stage height decreased by 0.03 to $0.55 \mathrm{~m}$ (mean $=0.19 \pm$ $0.08 \mathrm{~m}$ ) (Department of Water, Government of Western Australia unpubl. data). Differences in depth of some early dry season months (i.e. May to July) were not tested because of the limited number of monitored individuals and detections in these months. From the available data, diel vertical movements for May to July appeared to be similar in scale to those of the late dry season, but shifted to greater depths (Fig. 5).

The best fit and most parsimonious GAMM model describing $P$. pristis dry season depth use at a seasonal-scale involved the fixed effects water temperature, light intensity, moon illumination, and reach (Table 3). However, only temperature appeared to have a strong effect on $P$. pristis depth at this scale, with depth decreasing as temperatures increased (Table 3, Fig. 6a-c). P. pristis depth had a strong negative relationship with water temperature (Pearson product-moment correlation, $\mathrm{r}=-0.747$, $\mathrm{p}<0.001$ ), a 


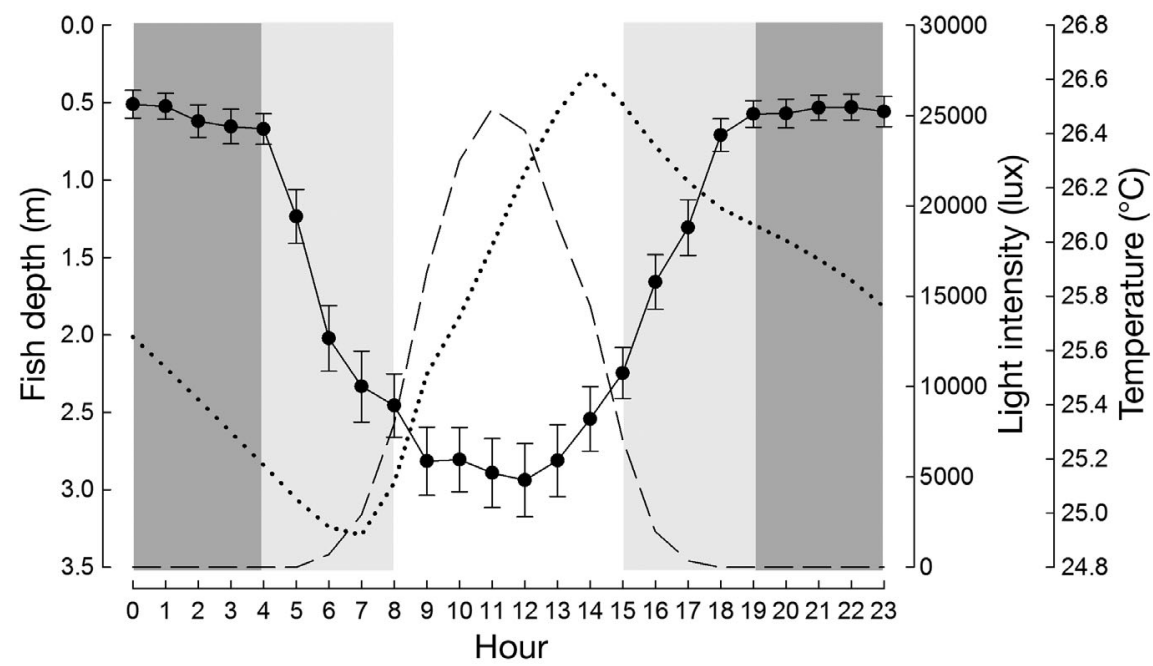

Fig. 4. Mean \pm SE hourly depths (solid line) of largetooth sawfish Pristis pristis (1675 to $2450 \mathrm{~mm} \mathrm{TL} ; \mathrm{n}=16$ ) continuously (over several months) monitored in the freshwater reaches of the Fitzroy River, Western Australia, in August through November 2008 to 2015, plotted with representative dry season light intensity (lux; dashed line) and temperature $\left({ }^{\circ} \mathrm{C}_{i}\right.$ dotted line) at $1 \mathrm{~m}$ depth. Depths of $P$. pristis were obtained from pressure sensors within deployed acoustic tags. Depth data for all individuals, times, and sites were pooled. Dark grey, light grey, and white shading denote night-time, twilight, and day-time hours, respectively. Pristis pristis occupied shallower waters in the night-time hours and deeper waters in the day-time hours. Pristis pristis depth had a stronger negative relationship with light intensity than water temperature

weak negative relationship with light intensity (Pearson product-moment correlation, $\mathrm{r}=-0.084, \mathrm{p}<$ 0.001 ) and a weak positive relationship with moon illumination (Pearson product-moment correlation, $\mathrm{r}$ $=0.134, \mathrm{p}<0.001)$ at a seasonal-scale.

On a diel scale, the best fit and most parsimonious model involved light intensity and water temperature for the investigated weeks in August (Week 34) and

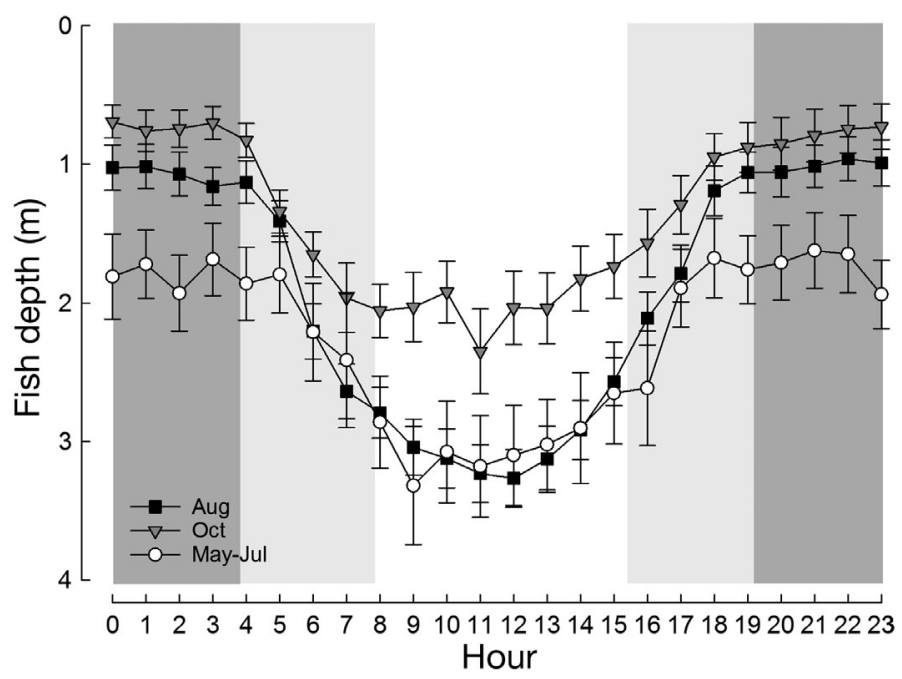

October (Week 43) (Table 3). This model suggested light intensity had a strong positive effect on $P$. pristis depth between 0 and 1000 lux, but this effect decreased at intensities $>1000$ lux (Fig. $7 \mathrm{a}, \mathrm{c}$ ). This model also suggested that water temperature had a strong negative effect on $P$. pristis depth occupation at relatively low temperatures (e.g. between 19 and $23^{\circ} \mathrm{C}$ in August and between 30 and $32^{\circ} \mathrm{C}$ in October) but not at relatively higher temperatures (i.e. 23 to $25.5^{\circ} \mathrm{C}$ in August, 32 to $33.5^{\circ} \mathrm{C}$ in October) (Fig. 7b,d). Results from the GAMM suggested that the influence of both variables appeared to diminish between investigated weeks (Fig. 7). P. pristis depth had a consistently moderate and positive relationship with light intensity for all weeks between August and October (Spearman rank-order correlation, $\mathrm{r}=0.407$ to 0.605 , mean $=0.577 \pm 0.02$, $\mathrm{p}<$ 0.001). Conversely, temperature and $P$. pristis depth had a negative relationship, which decreased with time. Starting with a moderate relationship in midAugust (Spearman rank-order correlation, $r=-0.406$, $\mathrm{p}<0.001$ ), the relationship between depth and temperature progressively decreased until Week 41 (i.e. early October) when no significant relationship was observed $(p>0.05)$.

Fig. 5. Comparison of mean \pm SE hourly depths of largetooth sawfish Pristis pristis monitored at all receivers in the freshwater reaches of the Fitzroy River, Western Australia, for each month(s) in the 2008 to 2015 dry seasons. August (early dry season) and October (late dry season) data-points represent data continuously (over several months) collected from 16 individuals (1675 to $2450 \mathrm{~mm}$ TL). May to July (early dry season) data-points represent data sporadically collected from 7 individuals (1780 to $2145 \mathrm{~mm}$ TL) and should thus be treated with caution. Water depths of $P$. pristis were obtained from pressure sensors within deployed acoustic tags. Depth data for all individuals and sites were pooled. Dark grey, light grey, and white shading denote night-time, twilight, and day-time hours, respectively. Depths of $P$. pristis vary between months of the dry season, with the greatest change in day-time depths between the cooler dry season months and the late dry season. Mean $P$. pristis depth differed between night-time hours of May-July and August, which may or may not be an artefact of the relatively few detections in May to July 
Table 3. Comparisons of generalised additive mixed models constructed to describe largetooth sawfish Pristis pristis depth use in the freshwater reaches of the Fitzroy River, Western Australia, on a diel and seasonal scale. Individual tags were treated as randomised variables (i.e. random $=\operatorname{list}($ Tag $=\sim 1)$ ) in each model. AIC: Akaike's information criterion; Light: hourly mean light intensity (lux) at $1.0 \mathrm{~m}$ depth; Temp: hourly mean water temperature $\left({ }^{\circ} \mathrm{C}\right)$ at $1.0 \mathrm{~m}$ depth; Moon: fraction of moon illuminated; Reach: location of sawfish; Tag: unique sawfish number; (-): not applicable

\begin{tabular}{|c|c|c|c|c|}
\hline Model & $\mathrm{df}$ & Diel (34) & $\begin{array}{l}\text { AIC/AIC Weight } \\
\text { Diel (43) }\end{array}$ & Seasonal \\
\hline Depth 1 & 1 & $2816.6 / 0.0$ & 1176.2/0.0 & $10866.5 / 0.0$ \\
\hline Depth s(Temp) & 5 & $2728.4 / 0.0$ & 1144.3/0.0 & $6332.6 / 0.0$ \\
\hline Depth s(Light) & 5 & $2275.5 / 0.0$ & $961.6 / 0.0$ & $10796.3 / 0.0$ \\
\hline Depth s(Moon) & 5 & - & - & $10790.8 / 0.0$ \\
\hline Depth s(Temp)+s(Light $)^{\mathrm{a}}$ & 7 & $1994.1 / 0.68$ & 930.3/0.16 & $6315.6 / 0.0$ \\
\hline Depth s(Temp)+s(Moon) & 7 & - & - & $6104.3 / 0.0$ \\
\hline Depth s(Temp)+Reach & 6 & $2730.4 / 0.0$ & 1143.6/0.0 & $6326.1 / 0.0$ \\
\hline Depth s(Light)+s(Moon) & 7 & - & - & $10730.0 / 0.0$ \\
\hline Depth s(Light)+Reach & 6 & $2274.8 / 0.0$ & $958.6 / 0.0$ & $10795.6 / 0.0$ \\
\hline Depth $\sim$ s(Moon)+Reach & 6 & - & - & $10790.1 / 0.0$ \\
\hline Depth $\sim$ (Temp)+s(Light)+s(Moon) & 9 & - & - & $6092.5 / 0.05$ \\
\hline Depth s(Temp)+s(Light)+Reach & 8 & $1995.6 / 0.32$ & $927.0 / 0.84$ & $6309.1 / 0.0$ \\
\hline Depth $\sim$ s(Temp) + s(Moon)+Reach & 8 & - & - & $6098.3 / 0.0$ \\
\hline Depth s(Light)+s(Moon)+Reach & 8 & - & - & $10729.2 / 0.0$ \\
\hline Depth $\sim$ (Temp) + s(Light $)+s($ Moon $)+$ Reach $^{b}$ & 10 & - & - & $6086.5 / 0.95$ \\
\hline
\end{tabular}
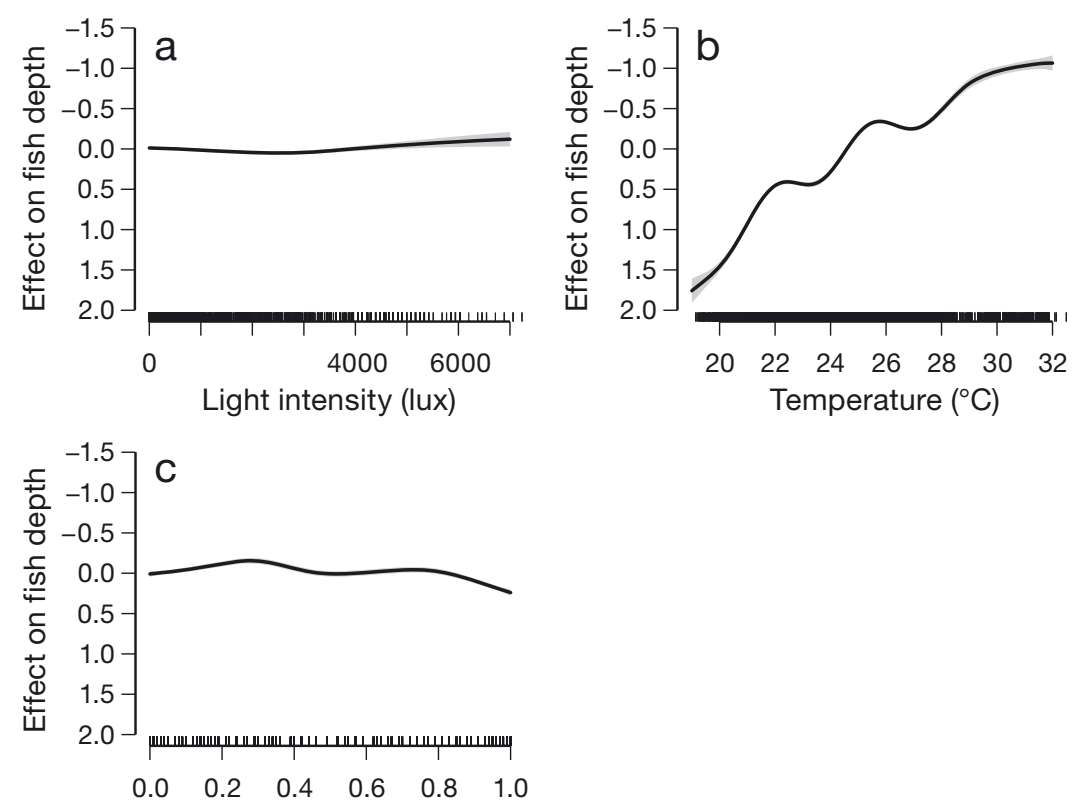

Fraction of the moon illuminated

Fig. 6. Generalised additive mixed model derived effects of (a) light intensity, (b) water temperature, and (c) moon illumination on depth of largetooth sawfish Pristis pristis tagged and monitored during the 2014 and 2015 dry seasons. Temperature, light, and depth data were detrended to focus on a seasonal rather than a diel-scale. Shaded regions represent $95 \%$ confidence bands. Rug marks on $x$-axis illustrate the distribution of abiotic variables. The effects of light intensity and moon illumination on $P$. pristis depth were negligible in comparison to water temperature. During the dry season, the depth P. pristis occupied decreased as water temperature increased

\section{Horizontal movements}

The number of visits at each receiver varied significantly throughout the day (chi-squared goodness of fit test, $\mathrm{df}=$ 23, $\mathrm{p}<$ 0.001). P. pristis avoided shallow glides and runs with low concentrations of large woody debris during day-time hours and showed a relative preference for these mesohabitats during night-time and some twilight hours (Figs. 2 \& 8). In Camballin Pool, $P$. pristis showed an affinity for deep habitats (i.e. pools and deep runs) with high concentrations of large woody debris in the day and a relative avoidance of these habitats at night (Figs. $2 \& 8$ ). In lower Myroodah Pool, P. pristis only demonstrated a minor preference for deep habitats in some twilight and day-time hours (Fig. 8). These results were generally consistent across all age-classes (i.e. $0+$ to $\sim 5+$ ).

Movement of $P$. pristis varied between periods of the day. On average, $48 \%$ of the distance that $P$. pristis travelled throughout a day occurred at night, $41 \%$ occurred during twilight, 

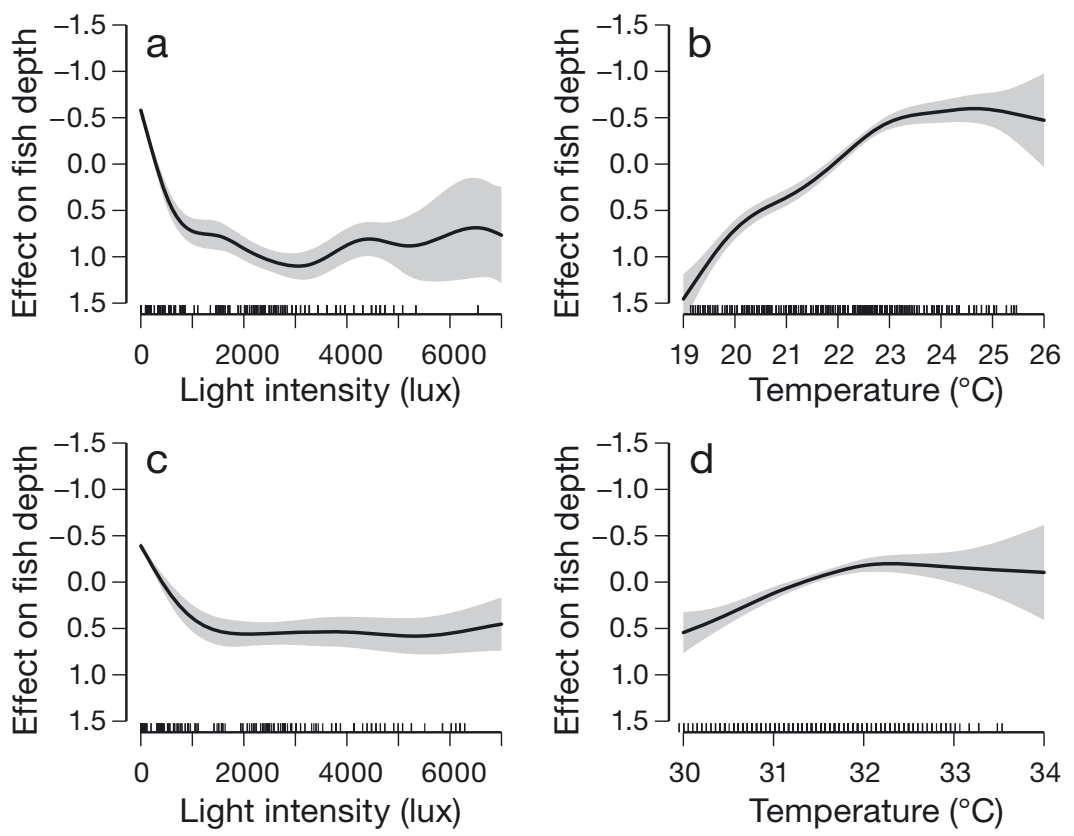

Fig. 7. Generalised additive mixed model derived effects of (a) light intensity and (b) water temperature on depth of largetooth sawfish Pristis pristis in Week 34 (early dry season) in 2014 and 2015 and the effect of (c) light intensity and (d) water temperature on P. pristis depth in Week 43 (late dry season) in 2014 and 2015. Shaded regions represent $95 \%$ confidence bands. The model suggests that the depth occupied by $P$. pristis increased with light intensity (up to 1000 lux) and decreased as water temperature increased, although to a lesser degree in the late dry season. Rug marks on $x$-axis illustrate the distribution of abiotic variables

and $11 \%$ occurred during daylight (Fig. 9a). Additionally, the number of receivers visited by individuals was also greater during night-time and twilight hours, although this difference was only significant (chi-squared goodness of fit test, $\mathrm{df}=23, \mathrm{p}<0.05$ ) for 5 of the 8 tested individuals (Fig. 9b). Consistent findings were observed throughout the dry season.

\section{Sawfish predator and prey relative abundance}

In 2014 and 2015, a mean minimum estimate of $104 \pm 7.1$ and $128 \pm 5.3$ freshwater crocodiles Crocodylus johnstoni occupied Camballin Pool and lower Myroodah Pool, respectively. Mean \pm SE relative abundance of $C$. johnstoni near glides (40.1 \pm $6.2 \mathrm{~km}^{-1}$ ) was not significantly different (Student's $t$ test, $\mathrm{df}=15, \mathrm{p}=0.344)$ than that in the other mesohabitats $\left(36.6 \pm 5.7 \mathrm{~km}^{-1}\right)$ at night. Few $C$. johnstoni were observed during the day, and these were typically found resting on land.

Seine netting conducted in the glides produced 24 fish species and 2 crustacean species. Known prey species of $P$. pristis that inhabit the Fitzroy River, such as cherabin Macrobrachium spinipes, bony bream Nematalosa erebi, and lesser salmon catfish Neoarius graeffei (Morgan et al. 2004, Thorburn et al. 2014), were present in the majority $(>50 \%)$ of the samples. Mean relative abundances of these 3 species were significantly greater within the shallow water environments at night than during the day (Student's $t$-test, $\mathrm{p}<0.05$ ). Day and night visual assessments also demonstrated an increase in abundance and diversity of fishes in shallow water environments at night.

\section{DISCUSSION}

Nurseries are often considered to be critical areas, which promote survivorship and recurring recruitment of juveniles (Castro 1993, Beck et al. 2001, Heupel et al. 2007). Removal of, or modifications made to, these nursery areas can greatly disrupt a population, forcing juveniles into less favourable environments and potentially decreasing recruitment of juveniles into the breeding population. It is necessary to know how a species uses the habitat within a nursery to construct effective conservation and management plans that would protect it from anthropogenic disturbances. This information is lacking for elasmobranchs in freshwater environments, including the Critically Endangered largetooth sawfish Pristis pristis. Through detailed observations of movements and habitat use of juvenile (primarily $>0+$ yr old) P. pristis, this study demonstrated for the first time that individuals move between riverine mesohabitats due to changes in multiple abiotic and biotic variables. Specifically, $P$. pristis in the dry season was found to occupy deep pools and runs in proximity to large woody debris by day and shallow water in glides, pool edges, and runs by night. Transitioning between these habitats occurred during twilight. Activity patterns also reflected this diel periodicity, with individuals moving more during night-time and twilight hours than day-time hours. Although shortterm (e.g. diel) movements of sawfishes are predominately governed by tides in mostly marine systems (e.g. Stevens et al. 2008, Papastamatiou et al. 2015) and by light intensity and tides in estuarine systems (Whitty et al. 2009, Simpfendorfer et al. 2010, 

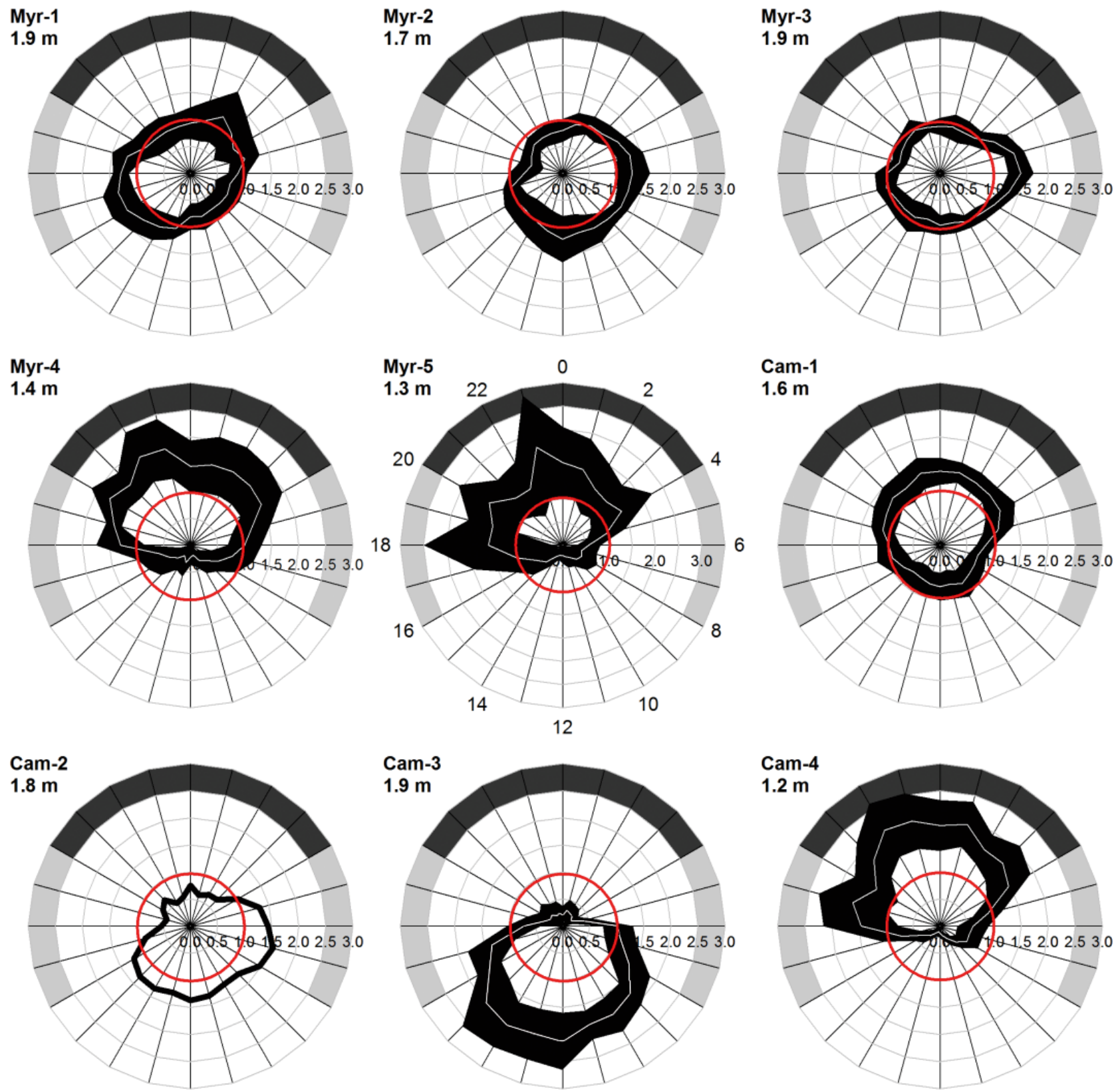

Fig. 8. Mean (white line) relative occurrence index values for respective hours and receivers/mean depths, with $95 \%$ confidence bands (black shading). Red circles highlight index values of 1 (values $>1$ : relative preference; values $<1$ : relative avoidance). Outer dark grey, light grey, and white shading denote night-time, twilight, and day-time hours, respectively. As an example, sawfish demonstrate a relative preference for Camballin Pool Receiver 3 (Cam-3) during the day-time hours and a relative avoidance of this area during the night-time hours. Only 1 individual was present when Cam-2 was active, and thus there is no mean value or confidence band for this receiver. See Table 2 and Fig. 3 for details of each site

Poulakis et al. 2016, Huston et al. 2017), light intensity was the primary cue for short-term movements of $P$. pristis in freshwater habitats, as it is for freshwater batoids (Neto \& Uieda 2012). Presumably, these light-based diel movements in P. pristis reflect twilight/nocturnal foraging and diurnal refuging behaviour.
Light-mediated movements of fish have often been associated with predator-prey interactions, with individuals moving to decrease predation risk or increase foraging efficiency (Scheuerell \& Schindler 2003, Hrabik et al. 2006, Andrews et al. 2009, Mehner 2012). Differences in the visual abilities or presence of extra-sensory organs in predators can 

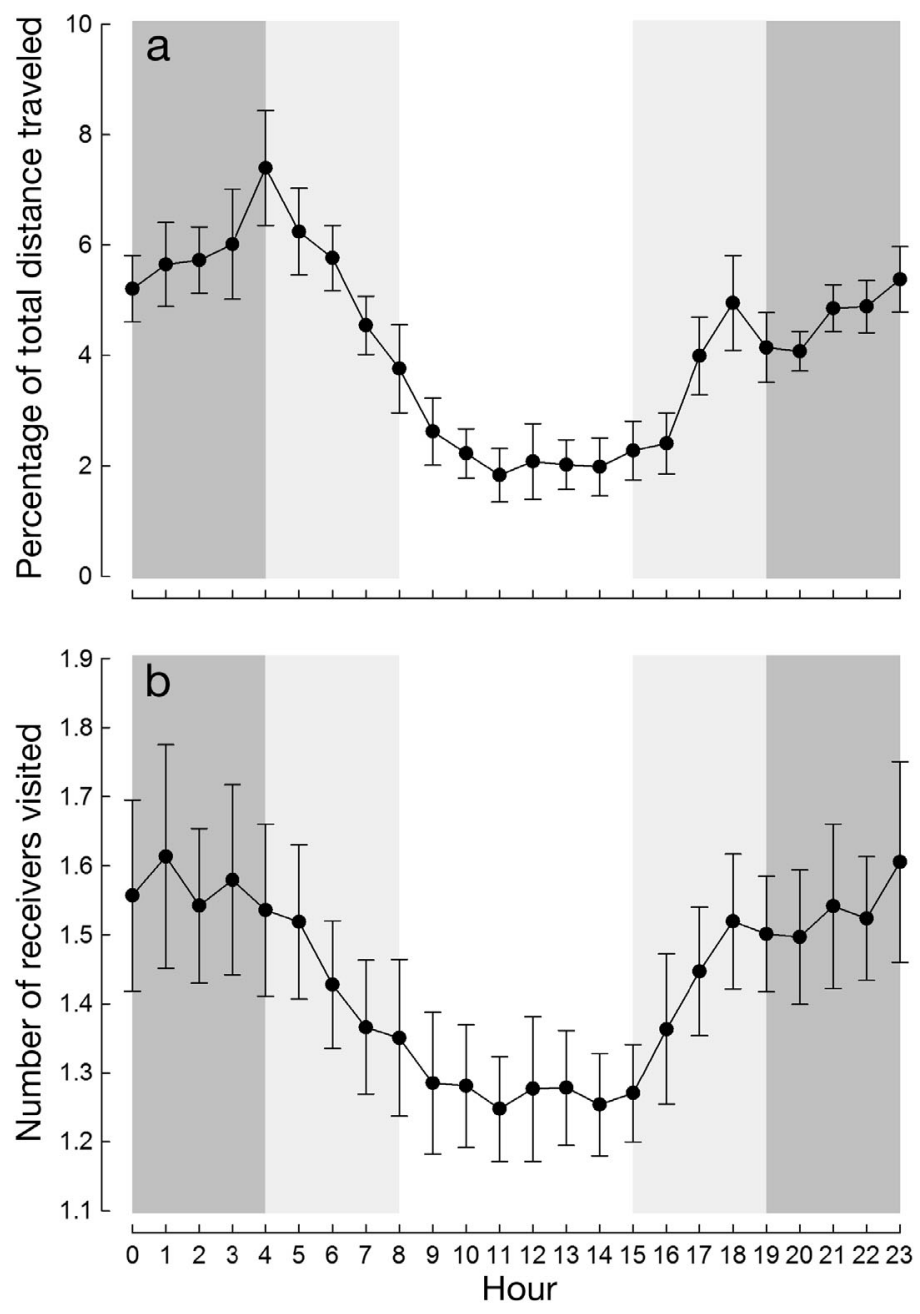

Fig. 9. (a) Mean ( \pm SE) percentage of the minimum distance travelled $d^{-1} h^{-1}$ and (b) mean $( \pm \mathrm{SE})$ number of receivers visited $\mathrm{d}^{-1} \mathrm{~h}^{-1}$. Dark grey, light grey, and white shading denote night-time, twilight, and day-time hours, respectively. Distance travelled and number of receivers visited by largetooth sawfish Pristis pristis was greater during night-time and some twilight hours than day-time hours

give these species an advantage over their prey in low or changing light intensities (Munz \& McFarland 1973, Nelson 2005). The high concentration of ampullae of Lorenzini on the rostrum of sawfishes provides this family with the ability to sense prey in dark and turbid waters (Wueringer et al. 2011). Moving into glides at night would also likely increase encounter rates between $P$. pristis and their prey, which are more abundant in shallow waters at night. The lateral striking action of the rostrum of a sawfish (Wueringer et al. 2012) would also be most effective in this vertically restricted habitat, which contains minimal if any complex structure (e.g. woody debris or macrophytes) (cf. Lundvall et al. 1999). The observed increase in abundance and increased catchability of prey would create an optimal environment for $P$. pristis foraging, which appears to help drive the movement of $>0+$ individuals into shallow environments (i.e. glides or runs) at night, as also suggested for 0+ individuals (Gleiss et al. 2016).

Fishes also move into shallower waters during twilight and night-time hours because of a perceived decrease in predation risk (Clark \& Levy 1988, Scheuerell \& Schindler 2003, Mehner 2012). The benefits of this strategy, however, would likely be limited for $P$. pristis. Species that are known to or that are likely to prey on sawfish, including the bull shark Carcharhinus leucas (Thorburn \& Rowland 2008, Thorburn et al. 2014), estuarine crocodile Crocodylus porosus (S. Peverell pers. comm.), and freshwater crocodile Crocodylus johnstoni (Morgan et al. 2017), have advanced non-visual sensory systems that allow these predators to effectively hunt in low-light conditions (Fleishman et al. 1988, Collin \& Whitehead 2004). In fact, underwater vision in crocodiles is poor regardless of light intensity (crocodiles are farsighted and unable to focus) and is believed to be of little use when hunting fishes (Fleishman et al. 1988). Furthermore, relative abundance of C. johnstoni was similar if not greater in shallow glides at night than in the other mesohabitats, which suggests that movement into glides at night would not decrease the encounter rates between the species. It thus can be argued that movement of $P$. pristis into shallow water at night is more heavily influenced by an increase in foraging efficiency than by a decrease in predation risk. Detailed monitoring of movement and activity of other sawfish predators (e.g. C. leucas) and prey (e.g. lesser salmon catfish Neoarius graeffei) in association with that of $P$. pristis would be useful in verifying this conclusion.

Although shallow depths occurred within the detection range of receivers in all mesohabitats, glides offered the greatest concentration of shallow and unobstructed habitat and thus provide $P$. pristis with ideal foraging grounds. The increased use of glides during night and some twilight hours indicates that this habitat is of importance to $P$. pristis during these periods. However, $P$. pristis were relatively mobile during twilight and night-time hours and moved between various mesohabitats throughout the reaches. Other benthic rays in marine and estuarine environments, including the smalltooth sawfish Pristis pectinata, also increase their area of activity at night, presumably to forage (Cartamil et al. 2003, Poulakis et al. 2016, Huston et al. 2017). Occurrence of P. pristis in multiple mesohabitats at night and twilight may stem from $P$. pristis using pools and runs as corridors 
while moving between or to glides located at the ends of each reach. Alternatively, it may simply be that sawfish foraged over small patches of shallow water within the detection range of receivers located in pools and runs. Regardless, it was clear that P. pristis moved between shallow water habitat during night-time and most twilight hours.

In contrast to night-time and twilight hours, during the day, $P$. pristis appeared relatively inactive, with movement between mesohabitats significantly reduced and restricted to deep pools and runs throughout the dry season. Smaller 0+ P. pristis are also less active in the day (Gleiss et al. 2016) but, unlike older age-classes, remain in shallow water through at least the early dry season in freshwater reaches and estuaries (Whitty et al. 2009, Gleiss et al. 2016). The freshwater and benthic ocellate river stingray Potamotrygon motoro and largespot river stingray Potamotrygon falkneri also exhibit diel and ontogenetic differences in depth use (Neto \& Uieda 2012), which are similar to those displayed by juvenile $P$. pristis. The ontogenetic differences in the behaviour of these 2 Potamotrygon species were suggested to be related to differences in feeding strategies or predator avoidance (Neto \& Uieda 2012). Ontogenetic differences in depth use of juvenile $P$. pristis and $P$. pectinata in estuarine habitats have also been suggested to develop as a result of differences in thermal preferences, prey type, and manoeuvrability of the different size classes (Whitty et al. 2009, Simpfendorfer et al. 2010). Differences in depth use between $0+$ and older cohorts of $P$. pristis within the freshwater reaches are also likely to be dictated by differences in the physiological requirements of the size classes but require further examination to determine the specific causal mechanisms.

Areas occupied by $P$. pristis in day-time hours were in the vicinity of large fallen and submerged trees. By virtue of the major annual wet season flooding in the Fitzroy River, pools exist on sweeping meanders and runs leading into them, where localised riparian scouring leads to an in-fall of trees and subsequent capture and deposition of drifting wood. In contrast, opposing and downstream inner portions of meanders frequently contain shallow sandbars. Therefore, it is difficult to decouple the importance of woody debris and deeper sections of a reach. Additionally, our acoustic monitoring data could only demonstrate P. pristis to occupy areas at a mesohabitat rather than a microhabitat-scale. As such, we were not able to ascertain if, or how, the species used large woody debris within pools and runs via these methods. However, previous active acoustic tracking within the monitored reaches revealed that juvenile $P$. pristis occupy spaces below or within outcroppings of large woody debris, often returning to the same structure each day after foraging at night (D. L. Morgan unpubl. data).

The importance of large woody debris as habitat for a subset of large-bodied endangered freshwater teleosts has been well established in large river systems with reduced wood loading and is the focus of river rehabilitation (e.g. Lieschke et al. 2015). An association with complex structural habitat, and notably mangroves, has been revealed by captures and telemetry of other species of sawfish, primarily P. pectinata (Simpfendorfer et al. 2010, Wiley \& Simpfendorfer 2010, Hollensead et al. 2016), the green sawfish Pristis zijsron (Morgan et al. 2015), and the dwarf sawfish Pristis clavata (Stevens et al. 2008). Complex structures like mangroves and large woody debris can provide fishes with flow refuge, provide greater surface area and structure for prey items to inhabit, and aid predator avoidance (Everett \& Ruiz 1993, Crook \& Robertson 1999, Nagelkerken et al. 2008). P. pristis would likely benefit most from decreased detection and access by predators during the day when P. pristis is less active. Although predation risk is likely to decrease with growth, large juvenile $P$. pristis (up to $1835 \mathrm{~mm}$ TL) have been observed with fresh bite marks from crocodiles and sharks (Morgan et al. 2017), suggesting that the threat of predation exists for multiple size classes.

Occupying deep mesohabitats during the day-time may also be thermally beneficial to P. pristis and can aid in reducing an individual's metabolism and energetic costs (Sims et al. 2006, Gleiss et al. 2016) until more profitable periods of foraging or fewer risks are present. However, the thermal benefits of these deep pools are likely to be minor during at least the early dry season when little difference exists between surface and bottom water temperatures (Whitty 2011, Gleiss et al. 2016). Temperature, or a correlated variable such as dissolved oxygen (see Baldwin \& Beauchamp 2002), appeared to have a greater effect on $P$. pristis depth at a larger temporal-scale (i.e. months). Additional active tracking and environmental monitoring is recommended, as is the use of video, to investigate the underlying cause(s) for the use of this deep-water habitat on a diel and seasonal scale.

Freshwater habitats compose $>95 \%$ of the $P$. pristis nursery area in the Fitzroy River and were thus the focus of this study. However, it is important to understand a nursery area as a complete system. P. pristis, which are often pupped within or near river mouths, may inhabit the lower estuarine regions of the Fitzroy 
River for $>6$ mo immediately post-pupping (prior to its upstream migration) and during its eventual transition into marine waters (Whitty et al. 2009, Whitty 2011). There are extreme differences between the estuarine and freshwater environments of the Fitzroy River, relating to tides, turbidity, salinity, and both the density and composition of prey and predator assemblages (Whitty 2011). As with most rivers, such differences are likely to give rise to alternative movements and behaviours of fishes. Indeed, habitat use of P. clavata (Stevens et al. 2008), P. zijsron (D. L. Morgan unpubl. data), and adult $P$. pectinata (Papastamatiou et al. 2015) in tidal creeks and marine waters is primarily driven by tides, rather than light intensity. Similarly, $0+P$. pristis in the estuarine region of the Fitzroy River move in the direction of flow when tides are present (Whitty et al. 2009). However, unlike their marine congeners, juvenile $P$. pristis also display diel vertical movements more similar to their respective age-classes in the freshwater reaches of the Fitzroy River (Whitty et al. 2009, Gleiss et al. 2016). The development of tide-governed movements is likely to be dependent upon the frequency and extremity of tides that individuals are exposed to. With only the less frequent large tides (9 to $>11 \mathrm{~m}$ ) affecting the Fitzroy River, their influence on $P$. pristis is likely diminished in comparison to areas outside of the river.

Deep pools and shallow environments, like glides, are important habitats for $P$. pristis. Restriction of flow or altering of river pathways could jeopardize such environments. The preservation of these instream habitats and how they are used by $P$. pristis, which varies ontogenetically, temporally, and spatially, should be considered for water resource planning, sustainable catchment management, and protection of this highly threatened species. The study has also indicated the potential importance of large woody debris and thereby the maintenance of riparian trees, from a land management perspective. Future studies should focus on obtaining a mechanistic understanding of diurnal sawfish interactions with predators and prey in deep pools, including close proximity to large woody debris, and developing landscape-scale models of riverine and estuarine nurseries for $P$. pristis throughout northern Australia.

Acknowledgements. This work was supported by Murdoch University and the Western Australian Marine Science Institution and funded by Chevron Australia, the Western Australian Government's State Natural Resource Management Program and the Department of the Environment and Energy Government of Australia. We are indebted to the Traditional Owners of the Fitzroy River and owe special thanks to the Nyingina-Mangala Rangers, Jarlmadangah Rangers, the Yiriman Project, Kimberley Land Council, Bunuba Rangers, Darngku Heritage Cruises, Bill and Mary Aitken, Department of Parks and Wildlife Western Australia, Mark Allen, Dean Thorburn and numerous other people for their assistance in the field. We thank Steve Beatty and Alan Lymbery for their insight into the statistical analyses. Gratitude also goes to Yeeda Station, Liveringa Station and Neville Poelina for providing access to their land and to Derby Mitre 10 for donating consumables for this project. We also thank the reviewers of this manuscript for their informative contributions. Finally, we thank Jim and Geraldine Kelly for use of their facilities during field work and the people of Derby and Fitzroy Crossing for their generous support of our work. This research was conducted under Fish Resources Management Act 1994 exemptions made available by the Western Australia Department of Fisheries. Animal ethics approval of this work was provided by Murdoch University's Ethics Board. This work was presented as part of the symposium 'Biology and Ecology of Sawfishes' at the 2016 annual meeting of the American Elasmobranch Society, which was supported by funding from the Save Our Seas Foundation, Disney Conservation Fund, and the American Elasmobranch Society.

\section{LITERATURE CITED}

Ackerman JT, Kondratieff MC, Matern SA, Cech J Jr (2000) Tidal influence on spatial dynamics of leopard sharks, Triakis semifasciata, in Tomales Bay, California. Environ Biol Fishes 58:33-43

Andrews KS, Williams GD, Farrer D, Tolimieri N, Harvey CJ, Bargmann G, Levin PS (2009) Diel activity patterns of sixgill sharks, Hexanchus griseus: the ups and downs of an apex predator. Anim Behav 78:525-536

Baldwin CM, Beauchamp DA (2002) Seasonal and diel distribution and movement of cutthroat trout from ultrasonic telemetry. Trans Am Fish Soc 131:143-158

* Beck MW, Heck KL Jr, Able KW, Childers DL and others (2001) The identification, conservation, and management of estuarine and marine nurseries for fish and invertebrates. Bioscience 51:633-641

Burnham KP, Anderson DR (2002) Model selection and multimodel inference: a practical information-theoretic approach, 2nd edn. Springer, New York, NY

Carlisle AB, Starr RM (2009) Habitat use, residency, and seasonal distribution of female leopard sharks Triakis semifasciata in Elkhorn Slough, California. Mar Ecol Prog Ser 380:213-228

Cartamil DP, Vaudo JJ, Lowe CG, Wetherbee BM, Holland KN (2003) Diel movement patterns of the Hawaiian stingray, Dasyatis lata: implications for ecological interactions between sympatric elasmobranch species. Mar Biol 142:841-847

Castro JI (1993) The shark nursery of Bulls Bay, South Carolina, with a review of the shark nurseries of the southeastern coast of the United States. Environ Biol Fishes 38: 37-48

Clark CW, Levy DA (1988) Diel vertical migrations by juvenile sockeye salmon and the antipredation window. Am Nat 131:271-290

* Collin SP, Whitehead D (2004) The functional roles of passive electroreception in non-electric fishes. Anim Biol Leiden Neth 54:1-25 
Crook DA, Robertson AI (1999) Relationships between riverine fish and woody debris: implications for lowland rivers. Mar Freshw Res 50:941-953

* Dulvy NK, Davidson LNK, Kyne PM, Simpfendorfer CA, Harrison LR, Carlson JK, Fordham SV (2016) Ghosts of the coast: global extinction risk and conservation of sawfishes. Aquat Conserv 26:134-153

Everett RA, Ruiz GM (1993) Coarse woody debris as a refuge from predation in aquatic communities. An experimental test. Oecologia 93:475-486

Everett BI, Cliff G, Dudley SFJ, Wintner SP, Van der Elst RP (2015) Do sawfish Pristis spp. represent South Africa's first local extirpation of marine elasmobranchs in the modern era? Afr J Mar Sci 37:275-284

Fleishman LJ, Howland HC, Howland MJ, Rand AS, Davenport ML (1988) Crocodiles don't focus underwater. J Comp Physiol A 163:441-443

*Gleiss AC, Morgan DL, Whitty JM, Keleher JJ, Fossette S, Hays GC (2016) Are vertical migrations driven by circadian behaviour? Decoupling of activity and depth use in a large riverine elasmobranch, the freshwater sawfish (Pristis pristis). Hydrobiologia 787:181-191

Hall LS, Krausman PR, Morrison ML (1997) The habitat concept and a plea for standard terminology. Wildl Soc Bull 25:173-182

Heithaus MR, Dill LM (2006) Does tiger shark predation risk influence foraging habitat use by bottlenose dolphins at multiple spatial scales? Oikos 114:257-264

Heupel MR, Carlson JK, Simpfendorfer CA (2007) Shark nursery areas: concepts, definition, characterization and assumptions. Mar Ecol Prog Ser 337:287-297

Holland KN, Wetherbee BM, Peterson JD, Lowe CG (1993) Movements and distribution of hammerhead shark pups on their natal grounds. Copeia 1993:495-502

*Hollensead LD, Grubbs RD, Carlson JK, Bethea DM (2016) Analysis of fine-scale daily movement patterns of juvenile Pristis pectinata within a nursery habitat. Aquat Conserv 26:492-505

Hrabik TR, Jensen OP, Martell SJD, Walters CJ, Kitchell JF (2006) Diel vertical migration in the Lake Superior Pelagic Community. I. Changes in vertical migration of coregonids in response to varying predation risk. Can J Fish Aquat Sci 63:2286-2295

Hugie DM, Dill LM (1994) Fish and game: a game theoretic approach to habitat selection by predators and prey. J Fish Biol 45:151-169

Huston CA, Stevens PW, Blaxton RM, Tolley SG, Scharer RM, Tornwall BM, Poulakis GR (2017) Diel movements of juvenile smalltooth sawfish: implications for defining the size of a nursery hotspot. Endang Species Res (in press)

Jennings DE, Gruber SH, Franks BR, Kessel ST, Robertson AL (2008) Effects of large-scale anthropogenic development on juvenile lemon shark (Negaprion brevirostris) populations of Bimini, Bahamas. Environ Biol Fishes 83: 369-377

*Kause J, Staaks G, Mehner T (1998) Habitat choice in shoals of roach as a function of water temperature and feeding rate. J Fish Biol 53:377-386

Kyne PM, Carlson J, Smith K (2013) Pristis pristis. The IUCN Red List of Threatened Species 2013:e.T18584848 A18620395. http://dx.doi.org/10.2305/IUCN.UK.2013-1. RLTS.T18584848A18620395.en (accessed 15 September 2016)

Lieschke JA, Lyon JP, Moloney PD, Nicol SJ (2015) Spatial partitioning in the use of structural woody habitat sup- ports the cohabitation of two cod species in a large lowland river. Mar Freshw Res 67:1835-1843

ㄴoundvall D, Svanbäck R, Persson L, Byström P (1999) Sizedependent predation in piscivores: interactions between predator foraging and prey avoidance abilities. Can J Fish Aquat Sci 56:1285-1292

* MacArthur RH, Pianka ER (1966) On optimal use of a patchy environment. Am Nat 100:603-609

* Matern SA, Cech JJ, Hopkins TE (2000) Diel movements of bat rays, Myliobatus californica, in Tomales Bay, California: evidence for behavioural thermoregulation? Environ Biol Fishes 58:173-182

Mehner T (2012) Diel vertical migration of freshwater fishes - proximate triggers, ultimate causes and research perspectives. Freshw Biol 57:1342-1359

Messel H (1981) The Blyth-Cadell Rivers system study and the status of Crocodylus porosus in tidal waterways of Northern Australia: methods for analysis, and dynamics of a population of C. porosus. (Surveys of tidal river systems in the Northern Territory and their crocodile populations: Monograph 1). Pergamon Press, Oxford

* Morgan DL, Allen MG, Bedford P, Horstman M (2004) Fish fauna of the Fitzroy River in the Kimberley region of Western Australia - including the Bunuba, Gooniyandi, Ngarinyin, Nyikina and Walmajarri Aboriginal names. Rec West Aust Mus 22:147-161

Morgan DL, Whitty JM, Phillips NM, Thorburn DC, Chaplin JA, McAuley R (2011) North-western Australia as a hotspot for endangered elasmobranchs with particular reference to sawfishes and the Northern River Shark. J R Soc West Aust 94:345-358

*Morgan DL, Allen MG, Ebner BC, Whitty JM, Beatty SJ (2015) Discovery of a pupping site and nursery for critically endangered green sawfish Pristis zijsron. J Fish Biol 86:1658-1663

* Morgan DL, Somaweera R, Gleiss AC, Beatty SJ, Whitty JM (2017) An upstream migration fought with danger: freshwater sawfish fending off sharks and crocodiles. Ecology 98:1465-1467

Munz FW, McFarland WN (1973) The significance of spectral position in the rhodopsins of tropical marine fishes. Vision Res 13:1829-1874

Nagelkerken I, Blaber SJM, Bouillon S, Green P and others (2008) The habitat function of mangroves for terrestrial and marine fauna: a review. Aquat Bot 89:155-185

Nelson M (2005) Target detection image analysis, and modelling. In: Bullock T, Hopkins C, Popper A, Fay R (eds) Electroreception. Springer, New York, NY, p 290-317

Neto DG, Uieda VS (2012) Activity and habitat use of two species of stingrays (Myliobatiformes: Potamotrygonidae) in the upper Paraná River basin, Southeastern Brazil. Neotrop Ichthyol 10:81-88

Papastamatiou YP, Grubbs RD, Imhoff JL, Gulak SJB, Carlson JK, Burgess GH (2015) A subtropical embayment serves as essential habitat for sub-adults and adults of the critically endangered smalltooth sawfish. Glob Ecol Conserv 3:764-775

Peverell SC (2008) Sawfish (Pristidae) of the Gulf of Carpentaria, Queensland Australia. MSc thesis, James Cook University, Queensland

* Phillips NM, Chaplin JA, Morgan DL, Peverell SC (2011) Population genetic structure and genetic diversity of three critically endangered Pristis sawfishes in Australian waters. Mar Biol 158:903-915

* Phillips NM, Chaplin JA, Peverell SC, Morgan DL (2017) 
Contrasting population structures of three Pristis sawfishes with different patterns of habitat use. Mar Freshw Res 68:452-460

* Poulakis GR, Stevens PW, Timmers AA, Stafford CJ and others (2016) Long-term site fidelity of endangered smalltooth sawfish (Pristis pectinata) from different mothers. Fish Bull 114:461-475

R Development Core Team (2013) R: a language and environment for statistical computing. R Foundation for Statistical Computing, Vienna. www.R-project.org

Scheuerell MD, Schindler DE (2003) Diel vertical migration by juvenile sockeye salmon: empirical evidence for the antipredation window. Ecology 84:1713-1720

Simpfendorfer CA, Freitas GG, Wiley TR, Heupel MR (2005) Distribution and habitat partitioning of immature bull sharks (Carcharhinus leucas) in a southwest Florida estuary. Estuaries 28:78-85

Simpfendorfer CA, Wiley TR, Yeiser BG (2010) Improving conservation planning for an endangered sawfish using data from acoustic telemetry. Biol Conserv 143: 1460-1469

Sims DW (2003) Tractable models for testing theories about natural strategies: foraging behaviour and habitat selection of free-ranging sharks. J Fish Biol 63:53-73

Sims DW, Wearmouth VJ, Southall EJ, Hill JM and others (2006) Hunt warm, rest cool: bioenergetic strategy underlying diel vertical migration of a benthic shark. J Anim Ecol 75:176-190

Stevens JD, McAuley RB, Simpfendorfer CA, Pillans RD (2008) Spatial distribution and habitat utilisation of sawfish (Pristis spp.) in relation to fishing in northern Australia. Report to Department of the Environment, Water, Heritage and the Arts, Australian Government, Canberra. www.environment.gov.au/system/files/resources/ d2b0bb03-401e-4e94-848f-85458e4d7d1e/files/sawfishreport.pdf (accessed 1 January 2017)

Thorburn DC, Rowland AJ (2008) Juvenile bull sharks Car-

Editorial responsibility: Gregg Poulakis (Guest Editor), Port Charlotte, Florida, USA charhinus leucas (Valenciennes, 1839) in northern Australian rivers. The Beagle: Rec Mus Art Galleries Northern Territory 24:79-86

Thorburn DC, Morgan DL, Rowland AJ, Gill HS (2007) Freshwater sawfish Pristis microdon Latham, 1794 (Chondrichthyes: Pristidae) in the Kimberley region of Western Australia. Zootaxa 1471:27-41

Thorburn DC, Gill HS, Morgan DL (2014) Predator and prey interactions of fishes of a tropical Western Australia river revealed by dietary and stable isotope analyses. J R Soc West Aust 97:363-387

*Werner EE, Mittelback GG, Hall DJ, Gilliam JF (1983) Experimental tests of optimal habitat use in fish: the role of relative habitat profitability. Ecology 64:1525-1539

White WT, Kyne PM (2010) The status of chondrichthyan conservation in the Indo-Australasian region. J Fish Biol 76:2090-2117

Whitty JM (2011) Utility of a multi-faceted approach in determining the habitat use of endangered euryhaline elasmobranchs in a remote region of northern Australia. MPhil dissertation, Murdoch University

Whitty JM, Morgan DM, Peverell SC, Thorburn DC, Beatty SJ (2009) Ontogenetic depth partitioning by juvenile freshwater sawfish (Pristis microdon: Pristidae) in a riverine environment. Mar Freshw Res 60:306-316

Wiley TR, Simpfendorfer CA (2010) Using public encounter data to direct recovery efforts for the endangered smalltooth sawfish Pristis pectinata. Endang Species Res 12: 179-191

Wood SN (2006) Generalized additive models: an introduction with R. CRC Press, Boca Raton, FL

*Wueringer BE, Peverell SC, Seymour J, Squire L Jr, Kajiura SM, Collin SP (2011) Sensory systems in sawfishes. 1. The ampullae of Lorenzini. Brain Behav Evol 78:139-149

* Wueringer BE, Squire L Jr, Kajiura SM, Hart NS, Collin SP (2012) The function of the sawfish's saw. Curr Biol 22: R150-R151

Submitted: October 2, 2016; Accepted: May 3, 2017 Proofs received from author(s): August 21, 2017 